\title{
Growth of Uttis (Alnus nepalensis) monitored in a trial plantation at Pakhribas, Dhankuta, Nepal
}

\author{
T. P. Barakoti ${ }^{1}$
}

\begin{abstract}
A long-term growth monitoring experiment on Uttis (Alnus nepalensis) was conducted in the permanent sample plots of the Agricultural Research Station (ARS) Pakhribas, Dhankuta for 10 years (1992-2001). The average annual increment in diameter at breast height was $2.14 \mathrm{~cm}$ in the $8^{\text {th }}$ year, and was $0.13 \mathrm{~cm}$ in the $16^{\text {th }}$ year of planting. The trees grew $44 \mathrm{~cm}$ to $130 \mathrm{~cm}$ per year irrespective of the age. The highest growth rate correspondend with higher rainfall during summer (March-April). Estimated biomass of stem and branches increased by 2-2.5 times within the 10 year period. Thinning and felling of the trees needed to provide better growing environment. The data would be useful for growth modelling and proper management of Uttis plantation in Nepal .
\end{abstract}

Key words: Nepalese alder vs Uttis, height, diameter, biomass, Pakhribas.

$A$ Inus nepalensis commonly known as Uttis in Nepal, few parts of India, Pakistan and Bangladesh, is an important multipurpose tree species. It grows in the cooler and moist areas of the northern temperate region of South-East Asia, China, Japan, and in South America. In Nepal, it is distributed from 900 to $2700 \mathrm{~m}$ (Lamichhaney, 1995) above sea level associated mainly with Prunus and Saurauria sp. in higher elevation and with Schima and Castanopsis sp. in the lower elevation. It is a pioneer species of degraded lands and is moderately shade tolerant (Storrs and Storrs, 1984) and colonizes well in gravel slip prone slopes (Jackson, 1987). As a nodule-forming non-legume, it has the ability to fix atmospheric nitrogen and improve soil. Its leaf alone can add $100 \mathrm{~kg} \mathrm{~N} \mathrm{ha}^{-1} \mathrm{yr}^{-1}$ to the soil (Postgate, 1978).

Endemic to Nepal (Burley and Stewart, 1985) and other mountain countries, Uttis is one of the most preferred forest tree species by the hill communities. It is fast growing, commonly used for fuel-wood, timber, furniture and leaf litter. It is also used as fodder for livestock, and shade to large cardamom (Ghimire, 1985) and teas (PAC, 1985) in the eastern hills. Its wood is used for industrial purposes (ply, match, tanning, chest for tea etc).

According to PAC (currently ARSP) annual record (1995), Uttis accounted for more than 50 per cent of the tree seedlings distributed from Pakhribas forest nursery for planting in the Koshi hills. Over the past 30 years, this species has been extensively planted throughout Nepal (Lamichhaney, 1984 and 1995).
In spite of extensive plantings, there is little information on silvicultural management of this species. There is no data record on thinning regimes and appropriate final plant spacing. Therefore, a longterm growth monitoring trial was felt and that was established to quantify growing rates on yearly basis for regular measurements. The information is useful for community forest users and forest managers in planning and management of Uttis in private and community forests. Such information will enable estimation of current annual increment, mean annual increment and to derive suitable rotations.

\section{Materials and methods}

The permanently established (planted in 1984 at $2 \times 2 \mathrm{~m}$ in collaboration of Forest Research Division) sample plots of Uttis (Alnus nepalensis, D. Don) in the north farm of ARS Pakhribas, Dhankuta at the elevation of 1850-1900 m was used for growth monitoring trial. Three squared plots of $32 \mathrm{~m}$ x 32 $\mathrm{m}(0.1 \mathrm{ha})$ were selected and laid-out in February 1992. The plantation was south facing Block I and Block III were located in medium slops, whereas Block II was in slight slop located between the above blocks but it was facing southeast. The trees within the boundaries and edge trees in the plots were marked and demarcated. Location map and plot chart showing each tree and identity number, site description (altitude, topography, slope, drainage, soil texture, natural vegetation etc.) of each plot developed. Measurements of diameter, and tree height in the trial blocks were carried out (once every year in January).

\footnotetext{
${ }^{1}$ Senior Scientist, Agricultural Research Station Pakhribas, Dhankuta. E-mail: tpbarakoti@yahoo.com, arspakh@ntc.net.np
} 
Diameter at breast height (DBH) measured over bark for all trees in each block (replication), while top heights were measured in 10 fattest selected trees/ block. DBH was measured before felling. The number of standing trees and felled trees are given in Annex 1. Height of trees and girth of logs were measured and yield of wood was estimated. Volume was calculated on the basis of mid-diameter of $3 \mathrm{~m}$ logs. The biomass of the harvested trees was also recorded. The data on major parameters were taken since 1992 and continued for 10 years. Fresh weight was converted into dry weight by multiplying with 0.41 -a relationship derived by Levenson (1979): $\mathrm{Y}=3.87+0.26$ a,

Where, $\mathrm{y}=$ dry weight yield $(\mathrm{kg})$, and $\mathrm{a}=\mathrm{dbh}^{2}(\mathrm{~cm})$.

Similarly, volume of stem was calculated according to volume equation (Sharma and Pukkala, 1990):

$\operatorname{Ln}(V)=(a+b) \ln (d b h)+c x \operatorname{Ln}(h)$,

Where $\mathrm{V}$ is total of volume stem with bark $\left(\mathrm{dm}^{3}\right)$, $\mathrm{a}=-2.7761, \mathrm{~b}=1.9006$, and $\mathrm{c}=0.9428$ $\mathrm{d}$ is diameter (in $\mathrm{cm}$ ) and $\mathrm{h}$ is height (in $\mathrm{m}$ ).

The number of stock trees and removed trees in each block was recorded every year. Up to $50 \%$ trees based on height, canopy close, DBH and density were thinned. The tree growth rate and ratio were calculated. In 1995, the bushes were partially cleared as there was difficult to move and take measurements. Tree height and DBH were measured that year in mid February.

\section{Results and discussion}

The major growth parameters like diameter and height were recorded from 1992 to 2001 and presented in Table 1 and Table 2 respectively.
Diameter at breast height-The average $\mathrm{DBH}$ increased from 17.23 to $28.00 \mathrm{~cm}$ over the ten years period (Table 1). The DBH was measured in all selected trees in each block. The average increment rate was from 0.13 to $2.14 \mathrm{~cm}$ (Table 1$)$. The higher rates were during the initial period, when the trees were small. The data showed that Uttis trees had gradual increase up to the final year of observation (2001), however the differences were found in decreasing trend.

Average tree height - The average height of Uttis plants varied from 15.73 to 22.40 m over the 10 years. Likewise, the average increment rates or differences were $0.44-1.30 \mathrm{~m}$ for different years (Table 2). The trees attained 5 to $6 \mathrm{~m}$ during the 9 years period. Unlike diameter, growth rates found higher during later period than the initial period. The heights were measured in the same 10 fattest trees, where the $\mathrm{DBH}$ were measured. The detail of measurement record is given in Annex 2.

According to 1995 records, average number of trees $\mathrm{ha}^{-1}$ after thinning was 673.8, 546.9 and 439.5 in Block I, II and III respectively. Normal stand is considered to be 900 trees ha ${ }^{-1}$ after thinning. A closer spacing might give a higher yield.

Biomass - The biomass was calculated based on the given table (Kharel and Mulder, 1984). Biomass of stem, branch and leaf are estimated separately (Table 3). The data revealed that stem and branches could produce similar yield (around $40 \mathrm{~kg}$ tree ${ }^{-1}$ each at $8^{\text {th }}$ year and above $100 \mathrm{~kg}$ tree ${ }^{-1}$ in $16^{\text {th }}$ year of planting). Leaves had smaller quantity of dry weight (5-11 kg/ tree) at $12 \%$ moisture.

Diameter and Hieght at other locations Various researchers had assessed growth measurement of Uttis in the past at different parts of the country. A summary of the result is presented here (Table 4) for comparison with the present result. It is obvious

Table 1 : Average diameter $(\mathrm{cm})$ increment in north farm, ARS, Dhankuta.

\begin{tabular}{cccccc}
\hline \multirow{2}{*}{ Year } & \multicolumn{4}{c}{ Diameter, cm } & \multicolumn{1}{c}{$\begin{array}{c}\text { Average } \\
\text { increment/year }\end{array}$} \\
\cline { 2 - 4 } & Block I & Block II & Block III & Mean & - \\
1992 & 17.1 & 14.1 & 20.5 & 17.23 & 2.14 \\
1993 & 19.5 & 15.8 & 22.8 & 19.37 & 1.63 \\
1994 & 20.9 & 17.6 & 24.5 & 21.00 & 1.67 \\
1995 & 22.4 & 19.3 & 26.3 & 22.67 & 1.40 \\
1996 & 23.6 & 20.7 & 27.9 & 24.07 & 1.36 \\
1997 & 24.9 & 21.9 & 29.5 & 25.43 & 1.24 \\
1998 & 26.0 & 22.9 & 31.1 & 26.67 & 0.73 \\
1999 & 27.4 & 23.3 & 31.5 & 27.40 & 0.47 \\
2000 & 27.7 & 23.9 & 32.0 & 27.87 & 0.13 \\
2001 & 27.4 & 24.5 & 32.2 & 28.00 & \\
\hline
\end{tabular}


Table 2 : Average height $(\mathrm{m})$ increment in North Farm, ARS, Pakhribas

\begin{tabular}{cccccc}
\hline Year & Block I & Block II & Block III & Mean & Increment rate \\
\hline 1992 & 17.5 & 12.0 & 17.7 & 15.73 & - \\
1993 & 17.7 & 12.9 & 17.9 & 16.17 & 0.44 \\
1994 & 18.0 & 13.3 & 18.6 & 16.63 & 0.46 \\
1995 & 19.3 & 14.3 & 18.9 & 17.50 & 0.87 \\
1996 & 19.8 & 14.6 & 19.8 & 18.07 & 0.57 \\
1997 & 20.5 & 15.0 & 20.5 & 18.67 & 0.60 \\
1998 & 21.2 & 15.7 & 21.0 & 19.30 & 0.63 \\
1999 & 22.8 & 16.8 & 22.2 & 20.60 & 1.30 \\
2000 & 24.6 & 17.2 & 22.8 & 21.53 & 0.93 \\
2001 & 25.3 & 18.4 & 23.5 & 22.40 & 0.87 \\
\hline
\end{tabular}

Table 3 : Biomass of Uttis (kg/tree) in ARS, Pakhribas:

\begin{tabular}{ccccc}
\hline \multirow{2}{*}{ Year } & DBH & Stem & Branch & Leaf \\
\cline { 3 - 5 } & & 41.5 & 39.5 & 5.4 \\
1992 & 17.23 & 52.7 & 51.0 & 6.4 \\
1993 & 19.37 & 61.9 & 62.4 & 7.3 \\
1994 & 21.00 & 69.5 & 70.0 & 8.0 \\
1995 & 22.67 & 78.6 & 79.3 & 9.0 \\
1996 & 24.07 & 86.8 & 87.0 & 9.8 \\
1997 & 25.43 & 91.6 & 92.2 & 10.4 \\
1998 & 26.67 & 95.5 & 96.3 & 10.8 \\
1999 & 27.40 & 97.2 & 98.1 & 10.9 \\
2000 & 27.87 & 100.0 & 101.0 & 11.0 \\
2001 & 28.00 & & & \\
\hline
\end{tabular}

that most of the data are close to the current findings. The DBH of the trees varied from 0.3 to $3.0 \mathrm{~cm}$ and the height from 0.6 to $2.7 \mathrm{~m}$, where the duration and age of trees are not identical (Table 4). Lamichhaney (1984 and 1995) emphasized the need of provenance identification within Nepal. Provenances from east Nepal showed taller height than that of far-western region (Clark, 1985).

Wood yield of Uttis was estimated to obtain $7.0 \mathrm{t} /$ ha/yr from a 15-year rotation grown on a moist domain in Ilam. In Kaskikot, a 6-year old plantation was estimated to yield $6.0 \mathrm{t} / \mathrm{ha} / \mathrm{yr}$ of fuel-wood (Kharel and Mulder, 1984).

\section{Conclusion}

The long-term growth monitoring data permit to draw the following conclusion and recommendations.
- $\mathrm{DBH}$ increment rate of Uttis decreases with the age of tree.

- No definite trend is followed in the rate of height increment, which may vary with growing environment.

- Faster growth of tree could be obtained preferably with regular and high precipitation during dry winter/summer months.

- Diameter and height of uttis are inversely proportional.

\section{Recommendations}

- Thinning should be done in plantations with $2 \mathrm{x} 2 \mathrm{~m}$ spacing after 5-6 years.

- Thinning and felling of undesired as well as slow growing small plants should be done regularly at an interval of 2-3 years.

Table 4. Annual average diameter and height increased per year in Uttis at different sites*.

\begin{tabular}{|c|c|c|c|c|c|c|}
\hline Site & Altitude & $\begin{array}{c}\text { DBH (cm) } \\
\text { per year }\end{array}$ & $\begin{array}{c}\text { Duration, } \\
\text { year }\end{array}$ & $\begin{array}{c}\text { Height (m) } \\
\text { per year }\end{array}$ & $\begin{array}{c}\text { Duration, } \\
\text { year }\end{array}$ & Reported by, in \\
\hline Banepa, Kavre & $1975 \mathrm{~m}$ & 1.5 & 16 & 1.4 & 16 & Lamichhaney, 1981 \\
\hline Nagarkot, Bhaktapur & $2150 \mathrm{~m}$ & 1.1 & 7 & 1.5 & 2.5 & NAFP, 1980 \\
\hline Godawari, Lalitpur & $1540 \mathrm{~m}$ & 0.3 & 4 & 2.0 & 2.5 & NAFP, 1980 \\
\hline Chalnakhel, Kathmandu & $1500 \mathrm{~m}$ & 3.0 & 9 & 2.7 & 9 & Lamichhaney, 1981 \\
\hline Thankot, Kathmandu & $1630 \mathrm{~m}$ & 2.2 & 17 & 1.5 & 17 & Lamichhaney, 1981 \\
\hline Jayakot, Kaski & $918 \mathrm{~m}$ & 2.2 & 7 & 1.6 & 7 & Lamichhaney, 1984 \\
\hline Palpa & & - & - & $0.6-1.0$ & 4.5 & Fonzon, 1986 \\
\hline Trisuli & & - & - & $7-10$ & 5 & - \\
\hline
\end{tabular}

* Source: (Cited in Lamichhaney, 1995) 
- Study on the effect of thinning on diameter, height and volume of Uttis is suggested to conduct for data confirmation.

\section{Acknowledgements}

The author would like to extend sincere gratitude to the station chiefs (Dr. K R Regmi and Mr. P L Karna) and Ex-Director (Mr. F. E. Tollervy of the then PAC) for their continuous support to manage and excute the long term experiment. Thanks are due to all officers and staff of the Station, who were directly involved in the conduction of this experiment. $\mathrm{Mr}$. C M Bhusal, who worked for the second half period of the research and involved in thinning, management, measurement and data recording.

\section{References}

Burley, J and Stewart, J L (eds). 1985. Increasing productivity of multipurpose species. IUFRO, Vienna, Austria.

Clark, J. 1985. Alnus nepalensis provenance trial. Report No.T-21/82, Pakhribas Agriculture Centre, Dhankuta, Nepal.

Fonzon, P. 1986. Forestry field trials, 1982-86. Tinau Watershed Project, Tansen, Nepal.

Ghimire, M P. 1985. Growing Alnus tree over cardamom plantation for fuel-wood in Ilam district. Occasional Paper No. 9, CFDP, Kathmandu, Nepal.
Jackson, J K. 1987. Manual of afforestation in Nepal. Nepal-UK Forestry Research Project, Kathmandu, Nepal.

Kharel, B..P. and Mulder, R.P. 1984. Fuelwood production in a plantation of Alnus nepalensis in the Phewa Watershed, Field Document No.16, HMG/FAO/UNDP, Kathmandu, Nepal.

Lamichhaney, B P. 1984. Variation of Alnus nepalensis D. Don in Nepal. M Sc. Thesis, TrinityCollege, Oxford, UK.

Lamichhaney, B P. 1995. Alnus nepalensis D. Don (A Detailed Study). FORESC Monograph 1/95. Forest Research and Survey Centre, Kathmandu, Nepal.

Levenson, B. 1979. Fuelwood utilization: a study of the demand and available fuelwood resources at six selected villages. Phewa Tal Technical Report No.9. Kathmandu, Nepal.

Pakhribas Agriculture Centre (PAC). 1985. A review of forestry and pasture trial work. PAC, Dhankuta, Nepal.

Postgate, J. 1978. Nitrogen fixation. The Institute of Biology, Studies in Biology: No.92, Arnold, p 4850 .

Storrs, A and Storrs, J. 1984. Discovering trees in Nepal and the Himalayas. Sahayogi Press, Kathmandu, Nepal. 


\section{Uttis Permanent Sample Plot, ARS Pakhribas}

\section{Annex 1. DBH and Height of 10 Fattest Trees}

\begin{tabular}{ccccccccc}
\hline $\begin{array}{c}\text { Block I } \\
\text { Tree No. }\end{array}$ & $\begin{array}{c}\text { DBH } \\
(\mathbf{c m})\end{array}$ & $\begin{array}{c}\text { Tree } \\
\text { height }(\mathbf{m})\end{array}$ & $\begin{array}{c}\text { Block II } \\
\text { Tree No. }\end{array}$ & $\begin{array}{c}\text { DBH } \\
(\mathbf{c m})\end{array}$ & $\begin{array}{c}\text { Tree height } \\
(\mathbf{m})\end{array}$ & $\begin{array}{c}\text { Block III } \\
\text { Tree No. }\end{array}$ & $\begin{array}{c}\text { DBH } \\
(\mathbf{m m})\end{array}$ & $\begin{array}{c}\text { Tree } \\
\text { height }(\mathbf{m})\end{array}$ \\
\hline 4 & 28 & 24.53 & 120 & 22 & 14.55 & 75 & 37 & 25.82 \\
5 & 31 & 23.46 & 143 & 25 & 17.48 & 79 & 33 & 23.01 \\
34 & 28 & 23.20 & 105 & 23 & 15.68 & 117 & 34 & 21.78 \\
37 & 29 & 21.03 & 107 & 24 & 18.10 & 18 & 32 & 21.70 \\
52 & 32 & 20.16 & 39 & 26 & 15.88 & 2 & 37 & 22.86 \\
86 & 27 & 25.18 & 13 & 24 & 18.77 & 19 & 32 & 21.69 \\
82 & 28 & 22.85 & 70 & 23 & 17.26 & 129 & 28 & 21.62 \\
118 & 29 & 23.62 & 103 & 23 & 16.00 & 78 & 29 & 22.21 \\
120 & 27 & 22.44 & 141 & 22 & 16.64 & 174 & 27 & 20.77 \\
143 & 24 & 21.86 & 177 & 21 & 18.23 & 164 & 26 & 20.47 \\
\hline
\end{tabular}

Annex 2.

Description of the numbers of trees in different blocks

Block No I

\begin{tabular}{|c|c|c|c|c|c|c|c|c|c|c|}
\hline \multirow{2}{*}{ Description } & \multicolumn{10}{|c|}{ Observation Years } \\
\hline & 1992 & '93 & '94 & '95 & '96 & '97 & '98 & '99 & '00 & 2001 \\
\hline $\begin{array}{l}\text { Total trees from } \\
\text { previous year }\end{array}$ & 219 & 111 & 79 & 69 & 69 & 59 & 47 & 38 & 35 & 35 \\
\hline No. of trees for removal & 108 & 32 & 10 & 0 & 10 & 12 & 9 & 3 & 0 & 2 \\
\hline No. of existing trees & 111 & 79 & 69 & 69 & 59 & 47 & 38 & 35 & 35 & 33 \\
\hline Removed trees, $\%$ & 49.3 & 28.8 & 12.7 & 0 & 14.5 & 20.3 & 19.1 & 7.9 & 0 & 5.7 \\
\hline Avg. diameter (cm) & 11.6 & 14.1 & 15.7 & 16.8 & 17.6 & 19.2 & 20.5 & 21.4 & 23.3 & 25.5 \\
\hline Wood extraction $(\mathrm{kg})$ & 2212 & 2580 & 2078 & not thinned & 1914 & 2212 & 2139 & - & - & - \\
\hline \multicolumn{11}{|l|}{ Block No II } \\
\hline \multirow{2}{*}{ Description } & \multicolumn{10}{|c|}{ Observation Years } \\
\hline & '92 & '93 & '94 & '95 & '96 & '97 & '98 & '99 & 2000 & 2001 \\
\hline $\begin{array}{l}\text { Total trees from } \\
\text { previous year }\end{array}$ & 179 & 87 & 64 & 56 & 56 & 47 & 40 & 35 & 35 & 32 \\
\hline No. of trees for removal & 92 & 23 & 8 & 0 & 9 & 7 & 5 & 0 & 3 & 3 \\
\hline No. of existing trees & 87 & 64 & 56 & 56 & 47 & 40 & 35 & 35 & 32 & 29 \\
\hline Removed trees, $\%$ & 51.4 & 26.4 & 12.5 & 0 & 16.1 & 14.8 & 12.5 & 0 & 8.6 & 9.4 \\
\hline Avg. diameter $(\mathrm{cm})$ & 9.9 & 11.5 & 13.6 & 14.9 & 15.8 & 17.6 & 18.5 & 19.4 & 22.3 & 23.5 \\
\hline Wood extraction (kg) & 1849 & 1864 & 1702 & not thinned & 1603 & 1685 & 1784 & - & - & - \\
\hline \multicolumn{11}{|l|}{ Block No III } \\
\hline \multirow{2}{*}{ Description } & \multicolumn{10}{|c|}{ Observation Years } \\
\hline & '92 & 93 & '94 & '95 & 96 & '97 & 98 & '99 & 2000 & 2001 \\
\hline $\begin{array}{l}\text { Total trees from } \\
\text { previous year }\end{array}$ & 174 & 82 & 53 & 45 & 45 & 38 & 29 & 22 & 22 & 22 \\
\hline No. of trees for removal & 92 & 29 & 8 & 0 & 7 & 9 & 7 & 0 & 0 & 2 \\
\hline No. of existing trees & 82 & 53 & 45 & 45 & 38 & 29 & 22 & 22 & 22 & 20 \\
\hline Removed trees, $\%$ & 52.9 & 35.4 & 15.1 & 0 & 15.6 & 23.7 & 24.1 & 0 & 0 & 9.1 \\
\hline Avg. diameter (cm) & 12.1 & 14.4 & 17.5 & 19.2 & 20.3 & 22.3 & 24.7 & 26.9 & 30.0 & 31.3 \\
\hline Wood extraction $(\mathrm{kg})$ & 2277 & 2439 & 1718 & not thinned & 1860 & 2035 & 1699 & - & - & - \\
\hline
\end{tabular}

